\title{
The pandemic/epidemic and solar terrestrial relation: A brief study with special reference to COVID-19
}

\author{
M Devi ${ }^{1,2}$, A. K.Barbara ${ }^{1}$, S Das $^{2}$, A Depueva $^{3}$, S Patgiri $^{2}$, A. Medhi ${ }^{2}$, M Saikia $^{2}$, R Mahato $^{4}$ and V. \\ Depuev $^{3}$
}

${ }^{1}$ Dept. of Physics, Gauhati University, Guwahati-14, Assam, India

${ }^{2}$ ST Radar Centre, Gauhati University, Guwahati-14, Assam, India

${ }^{3}$ IZMIRAN, Moscow, Russian

${ }^{4}$ Science College Kokrajhar, Kokrajhar, Assam, India

\begin{abstract}
The pandemic is the outbreak of a deadly virus that may affect the entire global population unlike an epidemic which confines to a city, region or a country. The word pandemic comes from the Greek pandemos meaning "pertaining to all people" as the deadly "new" virus was found to be easily human transmissible causing in general more numbers of deaths than epidemics. The past reports however show that both pandemics and epidemics could claim millions of lives with no treatment or instant remedies and perhaps, even at the present time these are the most serious threats to the existence of global community. Identification of the sources of the epidemic /pandemic outbreaks is extremely difficult mainly because of the inherent complex nature of the virus itself added by the non uniform records of infected-case data and in many cases reliability of the published /available reports. Therefore, such an attempt of source identification when tried with solar activity that started decades back both with statistical analyses and empirical relations, the results and analyses seem to vary from one to the other. However, with the progressive improvement in data quality and availability of compatible reports from wide platforms, one can expect now in attaining a comprehensive picture in identifying the sources associated with outbreak of such events. Therefore, in tune to the trend of earlier studies, the present paper examines the aspect of association on the outbreaks of such events with solar activity by analyzing the significant \& deadly epidemic/pandemic cases that occurred within 18 to 21 century. The contributions of
\end{abstract}


environmental aspects and atmospheric variabilities to mass causalities are also brought in to discussions in brief with special reference to the COVID-19 pandemics.

Keywords: Epidemic; Pandemic: Solar activity: Environment, Atmospheric variabilitues:

COVID-19.

\section{Introduction}

\section{Solar Activity, Epidemic and Pandemic:}

The first paper that claimed to have a connection between solar activity and influenza was published by Hope-Simpson [1978]. Hope-Simpson regarded influenza to be mainly associated with human responses to solar phenomenon, but not a contagious disease. The occurrences of six influenza 'pandemics' between 1918 and 1971 reported in his paper showed that the timing of each event was within \pm 1 year of a maximum in the sunspot cycle. Following this publication, series of papers, reports and documentations have come up associating sunspot activity and pandemics both through empirical relations and statistical analyses. The statistical work presented by Ertel [1994], Tapping et al. [2001], and Yeung [2006] conveyed that a relationship between sunspot numbers and pandemic influenza does exist. However, through statistical and hypothesis tests, the reliabilities of the above works were also brought in to the focus by many. But with all the criticisms, the study on "Relation between outbreak of epidemic /pandemic and solar activity" is continued as a topic with the aims to obtain a comprehensive conclusion perhaps possible now with the availability of reliable data sources.

The aim of this paper is also to examine the role of solar-cycles on the growth of epidemic/pandemic viruses and to identify possible involvement of environmental / meteorological aspects on the causalities caused by such deadly viruses.

\section{A brief historical background:}

A list of epidemic/pandemic cases documented from the published reports, is presented in Table I (source List of epidemics - Wikipedia and references therein), though there are a few variations in the occurrence dates from one source to the other. We, in this exercise will consider epidemic/pandemic events that occurred from eighteenth century to the recent COVID Pandemic of 2019. The cases for the analysis 
during the selected period are based mainly on the number of causality/death records that go beyond 50,000 , because high mortality rate in general, acts as one of the indices of virulence of an epidemic or pandemic event, along with other associated factors. We also note records of such high causalities caused by epidemics (mainly), even dates back from $1200 \mathrm{BC}$, but these events are at present not included in the analysis considering the in-compatibility in the mode of records, however a brief background on outbreaks of such significant pandemic/pandemic cases is presented now.

The past records reveal that the epidemic events are more frequent at locations where concentrations of people were a built in process. Like the Babylon influenza of $1200 \mathrm{BC}$, started in Persia (a peak centre of civilisation at that time), the $429 \mathrm{BC}$ Plague of Athens first reported from Greece, the same was the location for 412 BC epidemic, then these epidemic cases gradually shifted to Roman empire in 165 BC started with the outbreak of Antoine Plague (more than 5 million -10 million causalities). On the availability of better modes of communication and with the growth of activity centres all throughout the Europe, the outbreaks of epidemic started to spread even to Asia and Africa, converting the disease to a "pandemic" one and the 1st recorded pandemic i.e., the Plague of Justinian, the Bubonic Plague occurred on $541 \mathrm{AD}$ that continued till $747 \mathrm{AD}$ spreading over Rome, Byzantine Empire Bilad al-Sham, West Asia, Syria, Mesopotamia and Africa. The number of pandemic events then started to grow gradually all along the globe and the 2nd devastating pandemic occurred on 1346 (to 1353) AD spreading over Europe, Asia and North Africa, killing 75-200 million (10\%-60\% of European population). The records show that outbreak of large number of pandemics in the sixteen century had killed millions of people started with 1557-58 Influenza pandemic that covered Asia, Africa Europe and America. Along with the pandemic cases, the epidemic events also increased resulting to deaths of 5-10 million (40\% of population) in Mexico only by Small pox during 1519-1520 and in 1545. Again in the year 1576, a large part of population of Mexico (80\% and 50\%) lost their lives possibly in Salmonella enterica epidemic. The small pox epidemic in Chile during 1561 caused death of 20\%-25\% of native population. One of the deadly epidemic the Bubonic Plague then killed millions of people in London, England during 1563 1603,1665 ; Spain in the years $1582,1596,1647,1676$; Egypt during 1609 ; Italy in the years 1629 ,1740; Germany during 1632; France during 1668, 1720; Denmark, Sweden, Lithuania in1710 and in Balkans in 1738. But we now note that even with easy modes of travelling around the globe, the epidemic situations are now restrained within the country of its outbreak and even there are more epidemic events on 21 st century compared to pandemic cases (Figure 1), perhaps this is due to the awareness created in the society through enforcement of some 
protocols during such outbreaks and also assisted by advancement of technical and medical facilities. The past records also reveal that the epidemics of 18th century while caused casualties more than millions, the 21 st century pandemic events caused even less deaths (perhaps except for the current pandemic the COVID-19).

The brief historical background as presented above reveals as how an epidemic or a pandemic event could bring tragedy to global community with no instant remedy till a killer vaccine develops. No doubt, serious efforts are being put to identify the sources of growth of such deadly viruses especially in association with solar and geomagnetic activities, but we are still in a stage where prediction approach of such events is yet to be effective and more data inputs are welcome for framing of a future comprehensive precursive model. The paper thus aims at to examine possible existence of any relation between the onsets of pandemic/epidemic with solar activity. The biological aspects of the growth of a virus (either natural of artificial) will not be a part of this exercise. The cases for the analysis during the selected periods (from late 18th to the 21 st century) are based mainly on the causality/death records with numbers that go beyond 50,000 (Kindly see the attached list of events given in table I ).

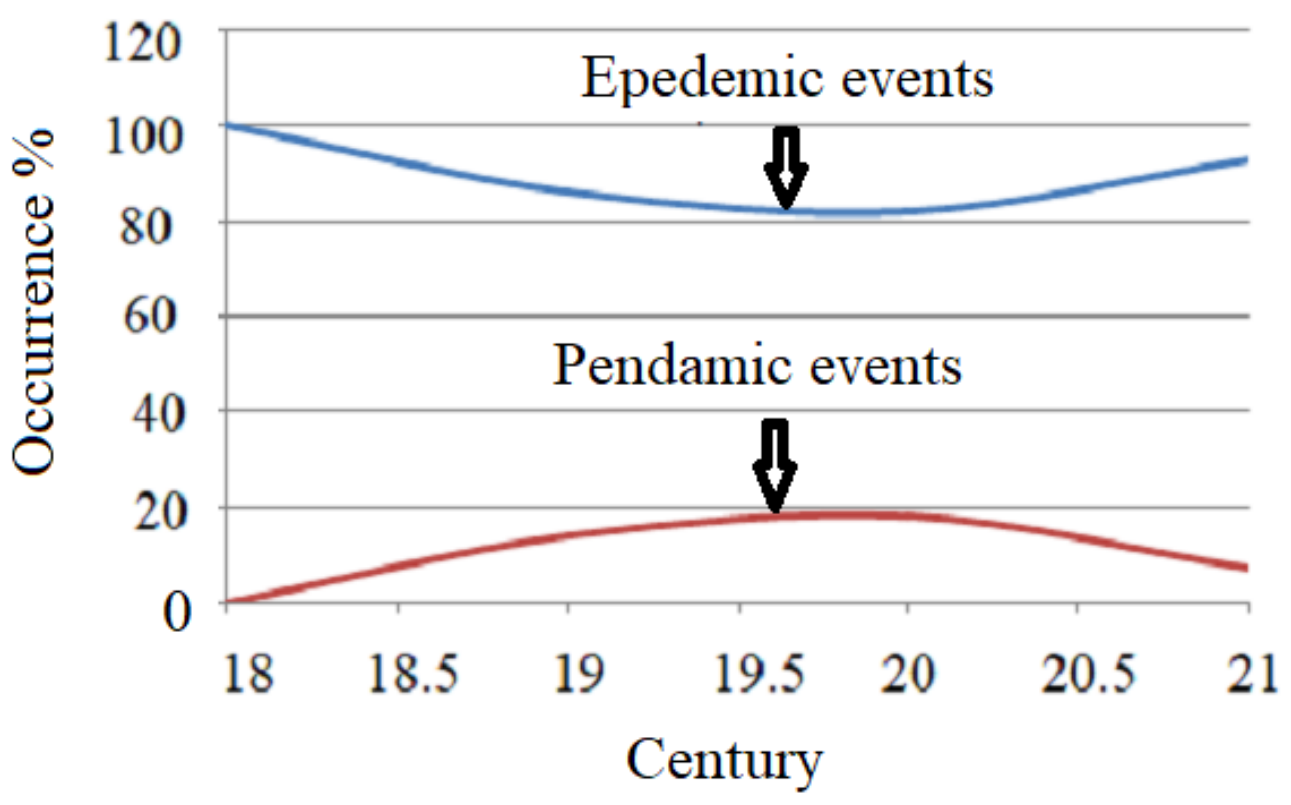

Figure 1 : Occurrence P.C of epidemic/pandemic from 18 to 21 Century 


\section{Analysis}

\subsection{Solar activity, Epidemics and Pandemics:}

One of the adopted parameters as an index of solar activity is the sunspot number (SN), the magnitudes of which reflect the activity of the sun.Therefore, the pandemic /epidemic events within the studied period will be examined with SN, to look for any association between the two in its 11 year solar cycles. In Figure 2, the SN status from 1730 to 2020 is displayed, where presence of 11 year $( \pm 1)$ solar cycles is visible and also that the activity of the sun varies drastically from one cycle to another as dictated by the peak value of the SN for that period. The epidemic/pandemic events from the Table I are now marked in the SN profiles as per the recorded year of outbreaks and these are displayed in Figures 3 (a-f).

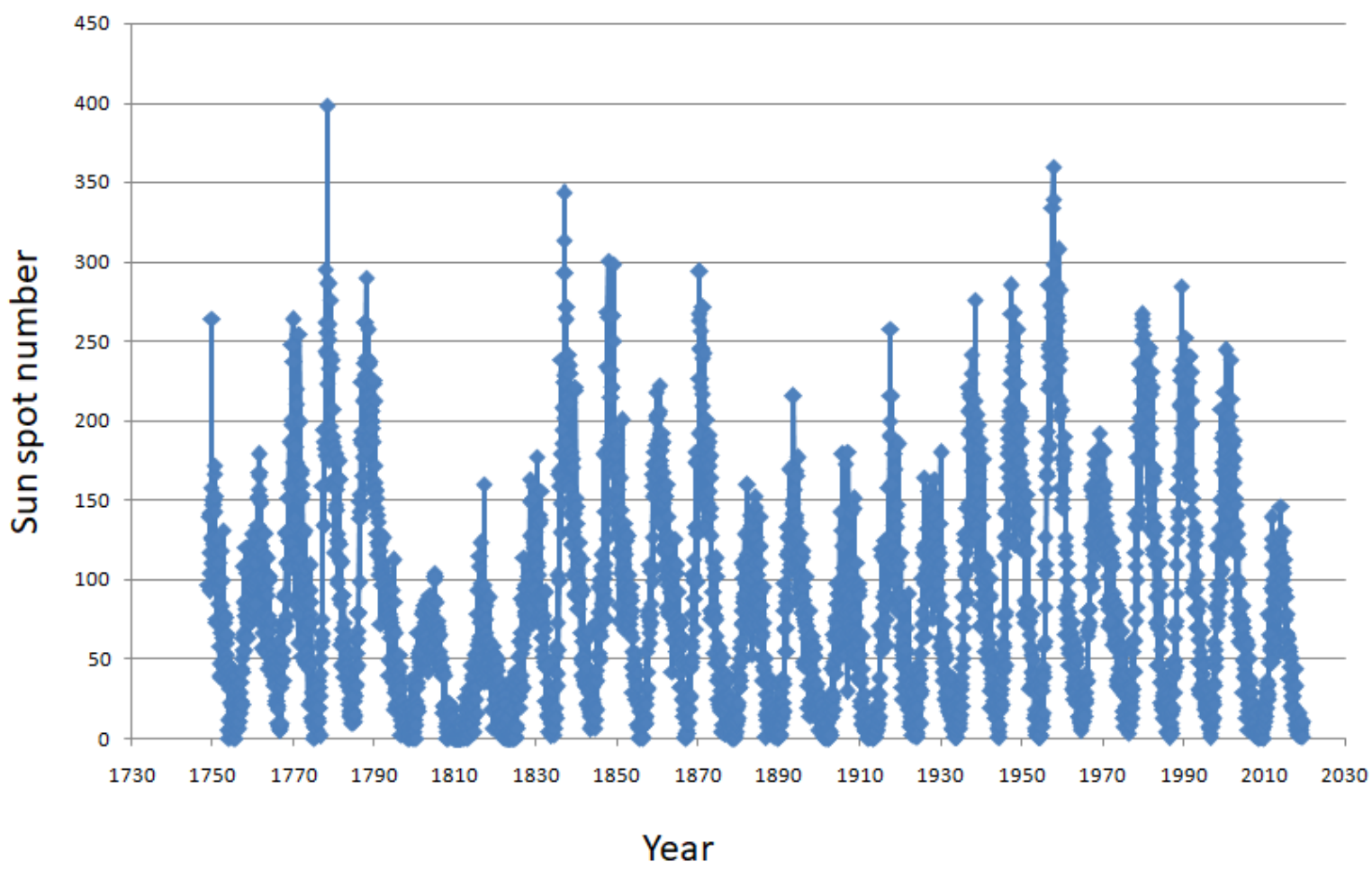

Figure 2 : Sunspot (SN) number variations from 1750 to 2019, displaying the 11 year solar cycle. The cycle to cycle SN peak may vary drastically signifying the strength of solar activity status. 


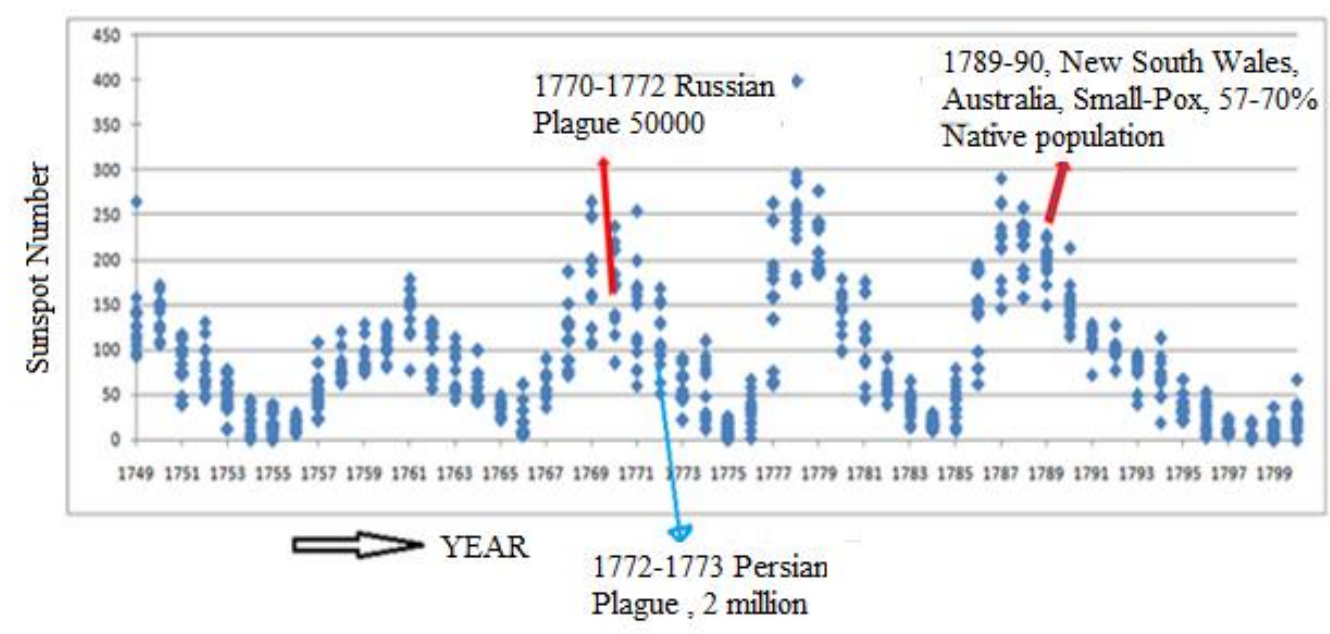

Figure 3(a): $18^{\text {th }}$ century epidemic/pandemic events, and SN profiles

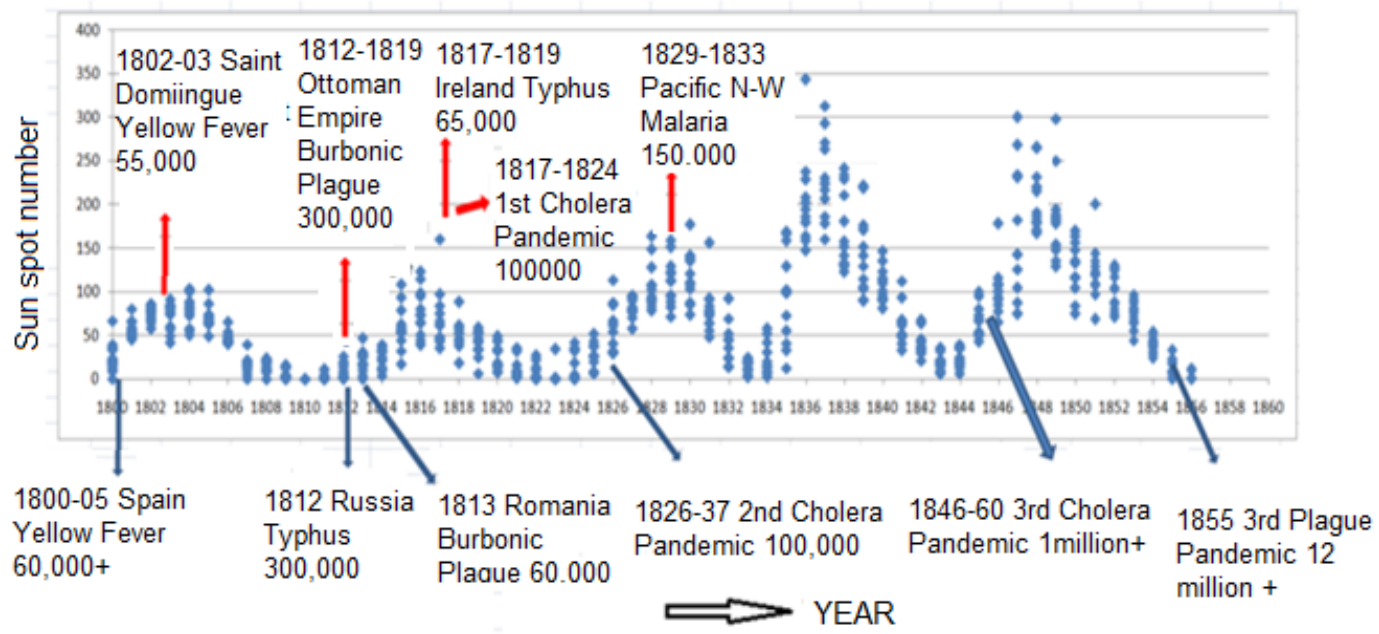

Figure 3(b): $19^{\text {th }}$ century epidemic/pandemic events (the number indicates causalities), and SN profiles 


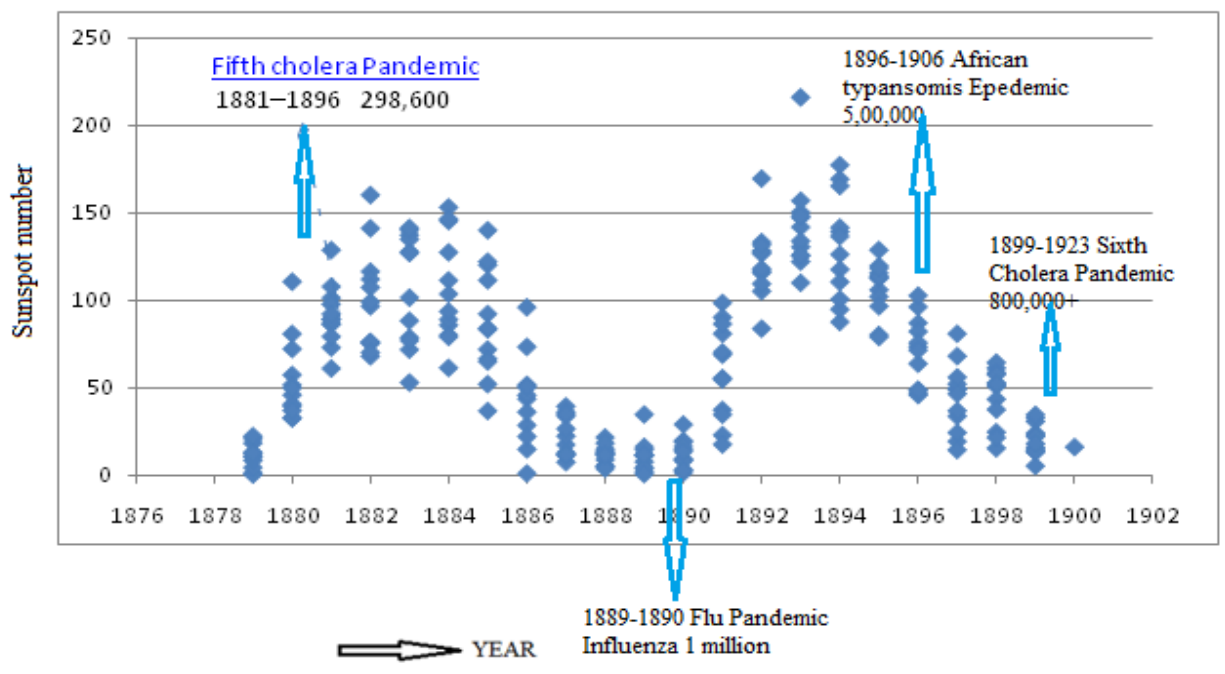

Figure 3(c): $19^{\text {th }}$ century events continued spreading to $20^{\text {th }}$ century and SN profiles

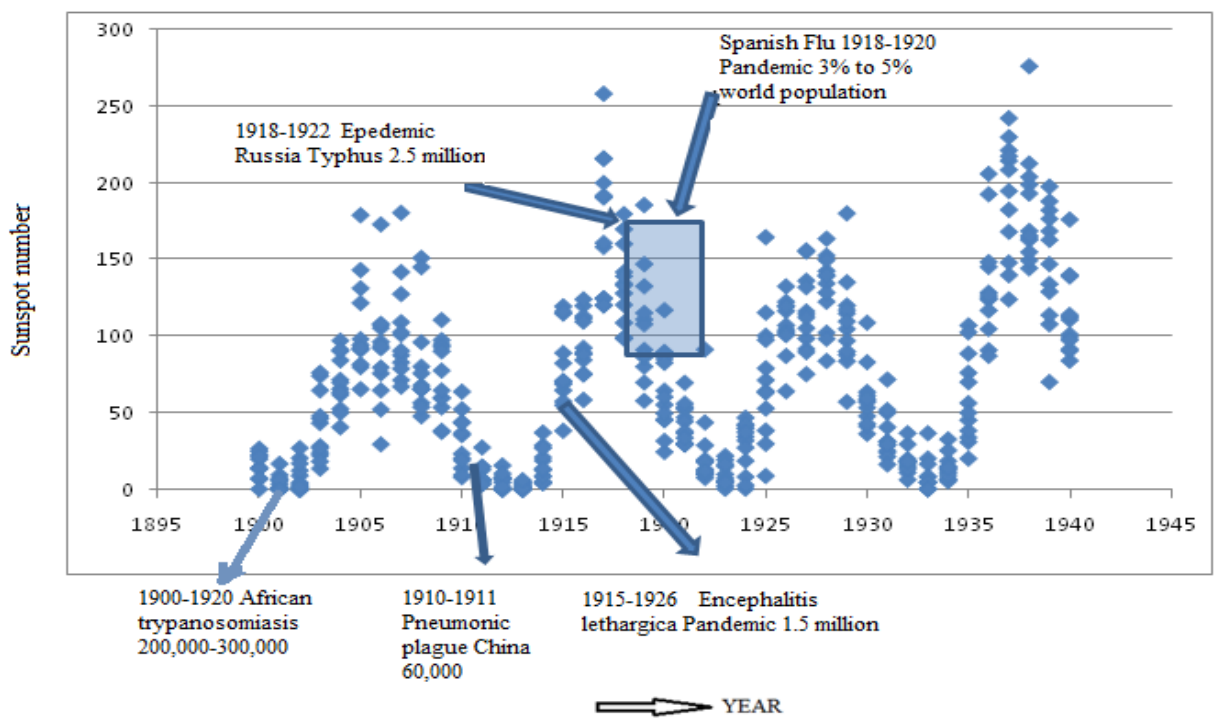

Figure 3(d) : $20^{\text {th }}$ century events , note that after the worst pandemic the Spanish flu of 1918-1920, no devastating events were documented up to early 1950 . 


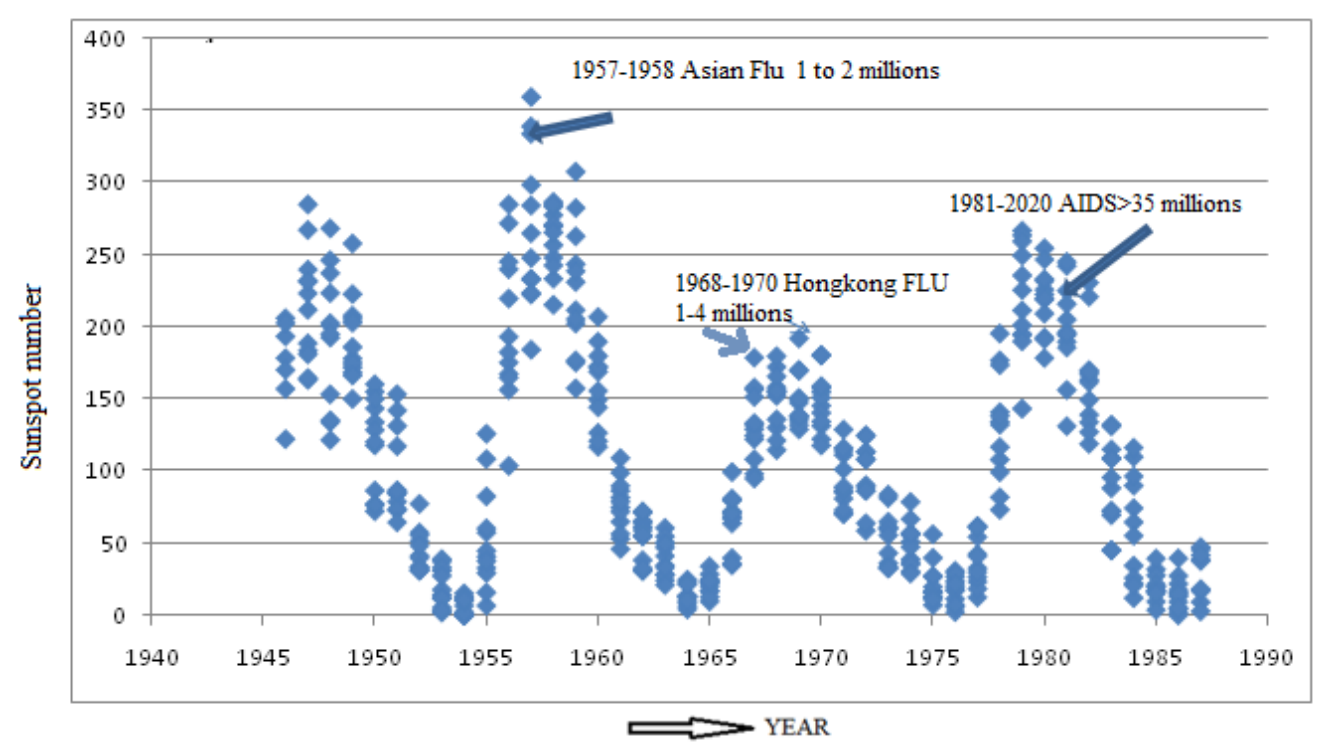

Figure 3(e): $20^{\text {th }}$ century events along with SN profiles

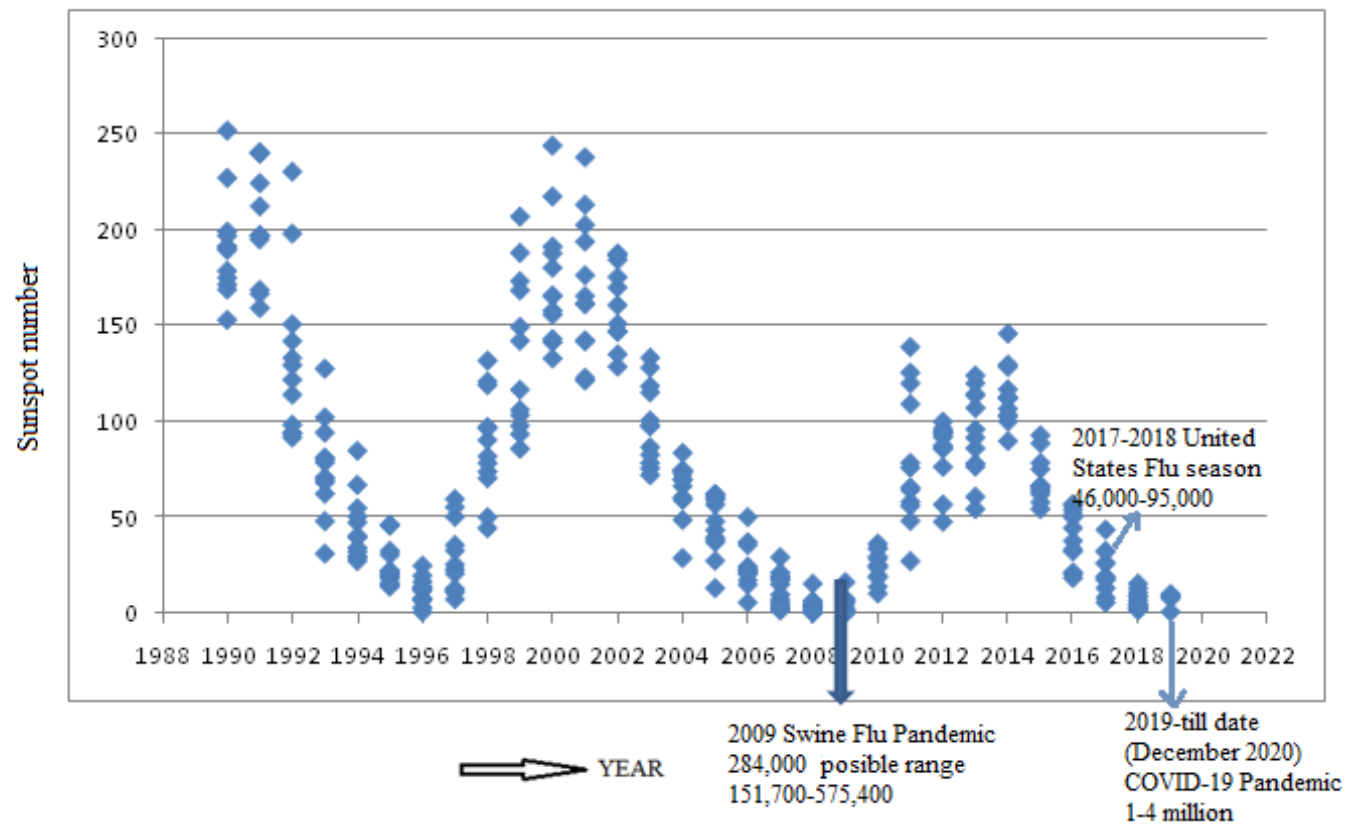

Figure 3(f): $20^{\text {th }}$ century events along with SN profiles; , note COVID -19 causalities)

The profiles of figure and Table 1 show that there was no record of any outbreak of devastating epidemic /pandemic events during 1988 to 2008 and maximum causalities are lower in number $(<10,000)$ ( Table I), compared to the large scale casualties occurred in other cases considered here. 
Finally the observational results from the Figures 3 ( a to f) are :

(i) Pandemic/epidemic events are significantly high in their occurrences at low solar activity periods.

(ii) A sizable number of outbreaks are also observed during the years with SN values that fall at $20 \%$ to $30 \%$ below the peak of the solar cycle.

(iii) Only a few cases are present during the peak solar status.

In the category (iii) above, the remarkable events are the 1st cholera pandemic of 1817, and Asian flu of 1957. The outbreaks of two extremely devastating pandemics, the Spanish flu [1918 ] and AIDS [1981, spread over years) occurred when activity reduces by $20 \%$ to $30 \%$ from the peak (category ii) and majority of epidemic/pandemic outbreaks occur towards the low solar activity status. The observations in Figures 3 are summarised in Figure 4 where occurrence P.C. of events at different solar activity status are presented. The $\mathrm{x}$-axis here gives the solar status where "1"corresponds to peak activity and the increase in numbers $(10 \% 20 \% \ldots . .$.$) . indicate activities are down by that P.C from the peak. The overall$ conclsion comes up from the analyses is that the solar minimum status provides a comfortable environment for the growth of epidemic/pandemic viruses and with the increase in the strength of the solar activity the sustainability power of a virus is likely to decline ( depending on the mutation process of a virus).

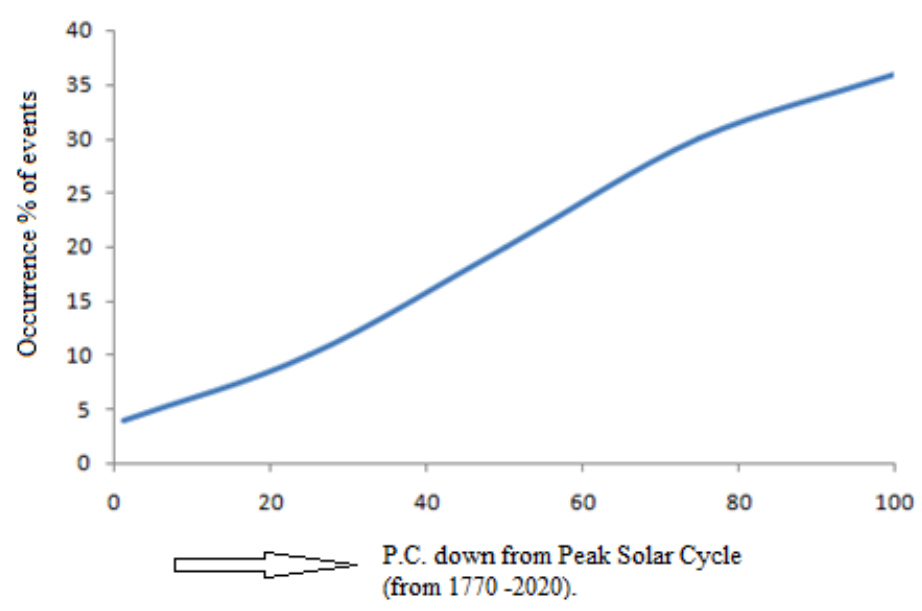

Figure 4 : Occurrence P.C. of epedemic/pandemic events ( during the study period) at different solar status . Here 1 ( in X-axis) corresponds to peak activity status, and increase in number $(20 \%, 30 \%$..) indicates activities are down by that P.C from the peak 
The strength of a solar cycle being highly variable from one to the other (Figures 2 and 3), dictated by the peak SN value ( which may be double in some cycles), a direct relation with SN ( instead of defining interns of high/low cycle) is likely to provide a qualified picture of solar control to the outbreak of epidemic/pandemic. Thus, the analysis is extended by grouping the events that occurred within a range of SN starting with 0-50 (minimum) to 250 to 300 (maximum) covering the studied period. The analyses outputs presented in the pie diagram of Figure 5, display how percentage contribution of each range of solar activity (represented by sunspot number) varies in the outbreak of pandemic /epidemic events, to the total occurrences during the period 1880-2019. The conclusion that comes from the analysis is that weak solar radiation with SN between 0-50 provides a comfortable environment for growth of the epidemic/pandemic viruses and this factor goes to a minimum as SN reaches peak values of 250-300 of a cycle when only a few fraction of events did occur at this range. It is also significant that for the $\mathrm{SN}$ value lying within 100 to 200 , the P.C contributions of solar activity to the outbreak of events are not distinguishable irrespective of whether it represents the peak of a solar cycle or it lies at $20 \%-30 \%$ at its shoulder. Therefore defining the outbreak event in relation to SN seems more realistic.

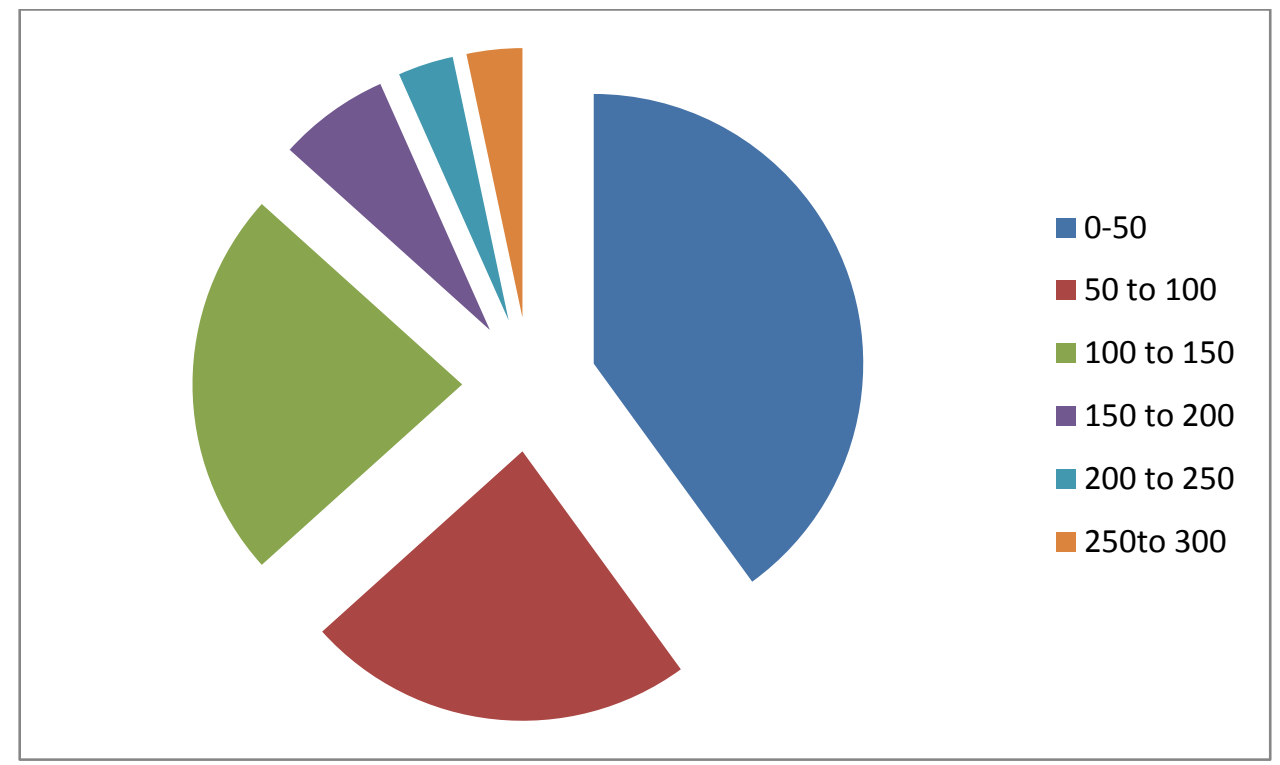

Figure 5:The pie diagram displays contribution of each range of solar activity ( represented by sunspot number ) in the outbreak of pandemic /epidemic events, to the total occurrences: [period 1880 - 2019] . 


\subsection{Seasonal/ environmental contributions to the spread /inhibition of pandemic/epidemics:}

It is also important to bring the issue on the spread and sustenance of a pandemic/epidemic once the virus is grown. We have seen that the SN acts an important index in the growth of a pandemic/epidemic virus but for its spread and sustenance, the involvement of many other factors including the environment, the weather and climatic situations of a location cannot be brushed aside. One serious constrains for such analysis is non availability of well documented data of the cases with precise records of onset time and season. But during the covid-19, the availability of continuous global data of the infected cases as well as of causalities on daily basis provides requisite parameters for taking up this pandemic event as a test case for seasonal role on the growth/sustenance of the virus . Starting with the outbreak of this event detected first in December 2019 in China (Zhu et al., 2020), its growth perhaps could be linked with the winter season, and from there it's spread to France, the rest of Europe, and then to the other continents of the was clear.The first few countries suffered seriously by this pandemics that came to the surface in the month of March 2020 are Italy, France , Spain then from there, it spreads to other European countries, further to America and to Asia. Therefore, the study period will be from equinoxial month of March 2020 to the year ending in December 2020. Further, the spread of such epidemic/pandemics as are largely dependent on the social awareness, protocols imposed by the concerned administrators and also on availability of killer vaccine, the period of study is so selected that the full protective measures for containing the pandemic are not generally possible within this short span of time, except for a few countries. Thus, it is to be remembered that we will consider the pandemic case distribution pattern only for the initial phase of the attack, further, the spread of the event being controlled by many factors as mentioned, these aspect will not be dealt with here. A few representative profiles of daily recorded infected cases from different countries for period as defined, are presented in Figure 6 ( collected from respective website).Such records from Italy (Figure 6a), show a sudden enhancement in the pandemic cases in the winter season (increase in March is not considered as the outbreak was sudden), a similar status is also reported from Russia, when an exponential growth of cases did occur as winter approaches ( Figure 6b). Many European countries (irrespective of their latitudes and altitudes) also experienced more cases in winter ( Figure $6 \mathrm{c}$-d). In southern hemisphere too, as one can see from two representative case profiles (Figure 6 e-f) ) of South Africa and of Australia, that more active cases got surfaced during winter. Thus winter environment apparently supports in the growth process of the 
COVID-19 virus. However in countries like India (Figure 6g ). and Pakistan ( not shown) the infected cases show record high mainly during summer or late summer and started declining as winter approaches .Thus, it is perhaps necessary to understand or analyse the basic habits of the people of a particular country, society, and the factors leading to such changes in seasonal role in spreading of the same Virus.

\section{Daily New Cases in Italy}

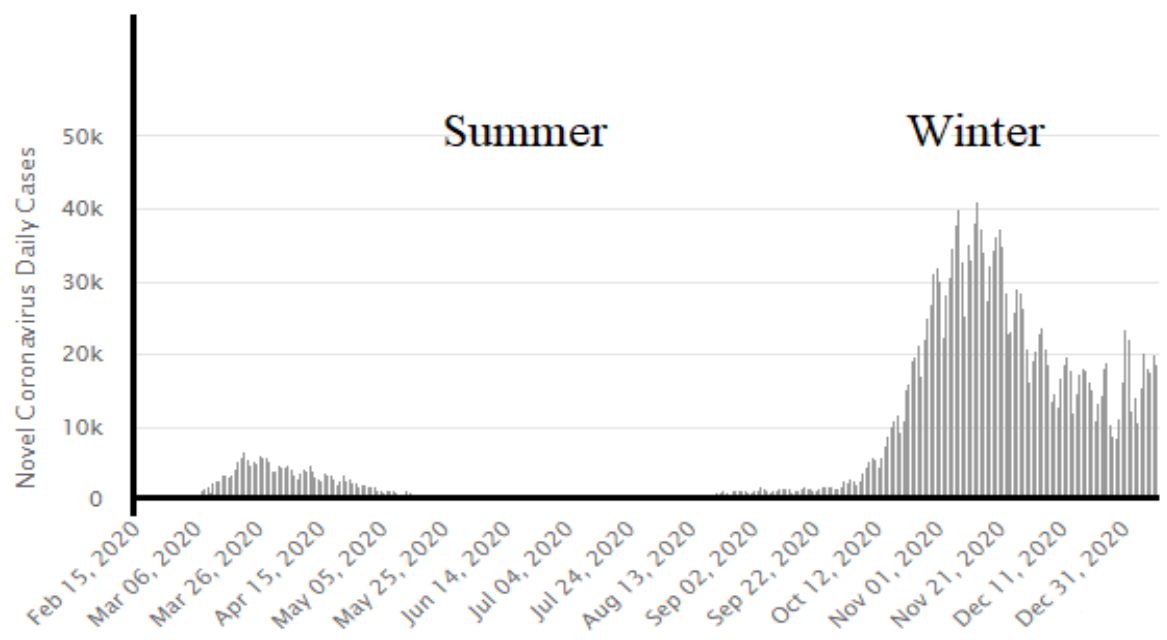

(a)

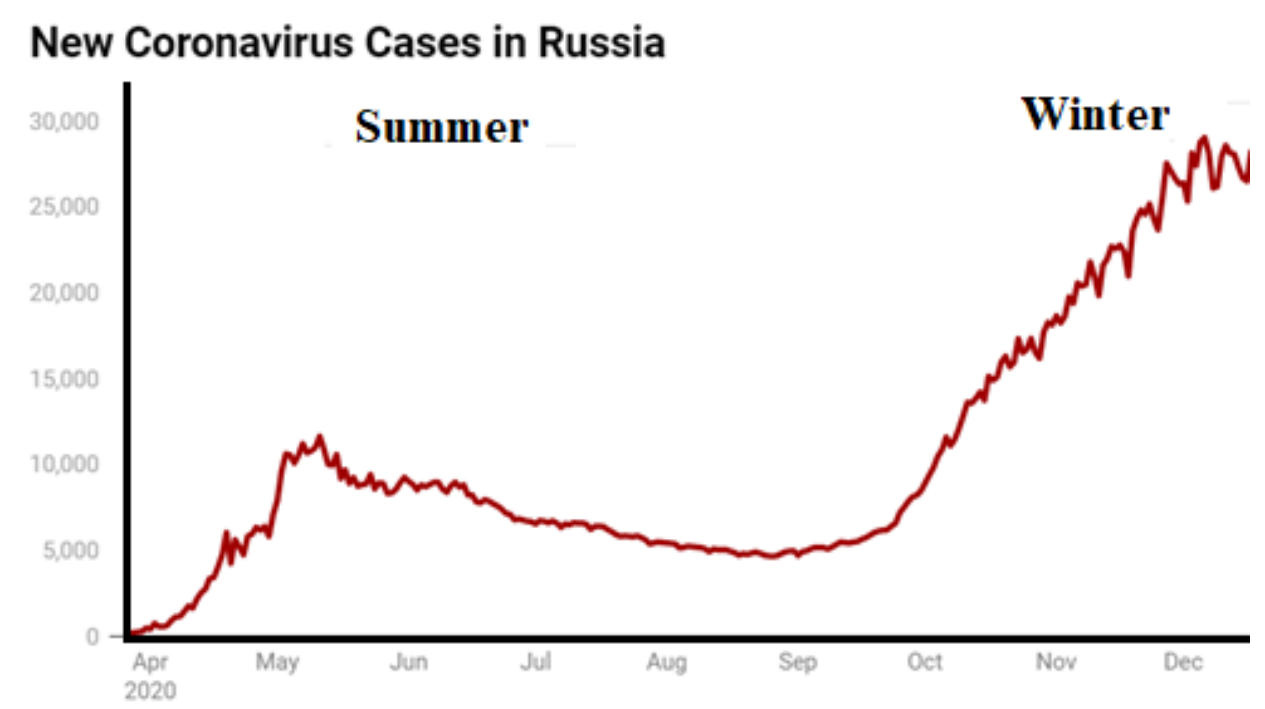

(b) 
International Journal of Electronics and Applied Research (IJEAR) vol. 7, issue 2, Dec 2020 Online (http://eses.net.in/online_journal.html)

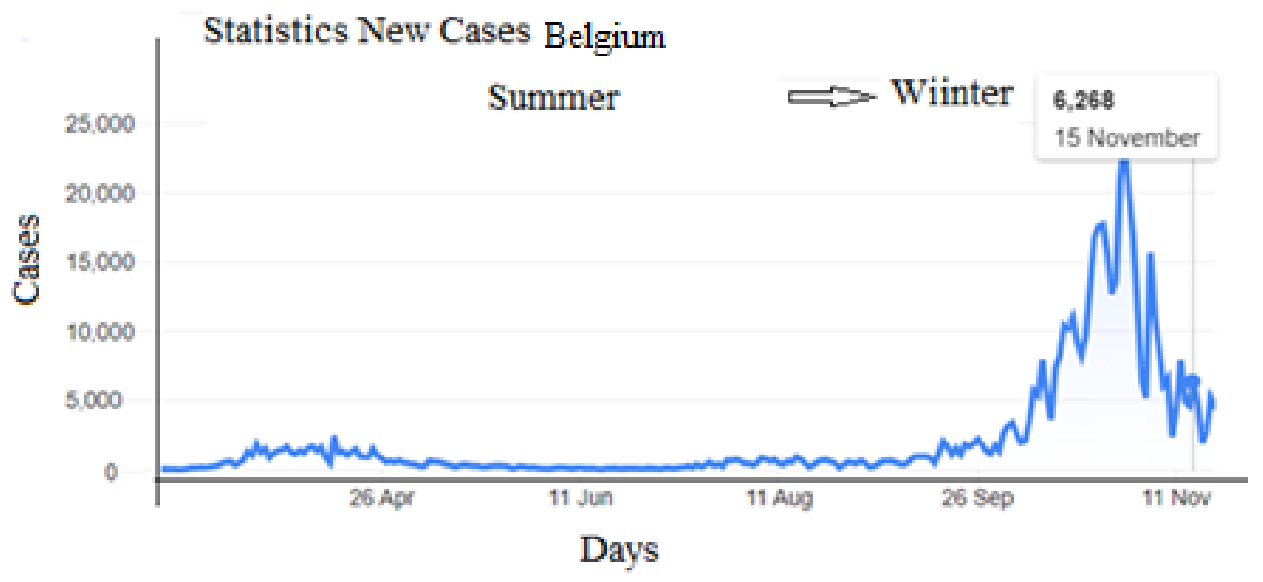

(C)

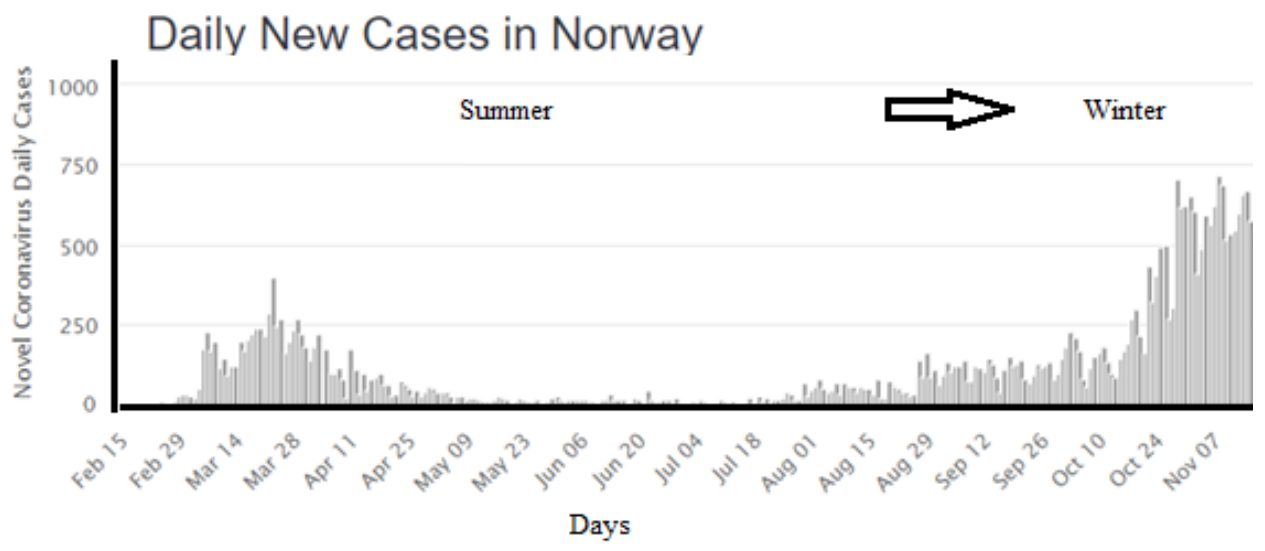

(d)

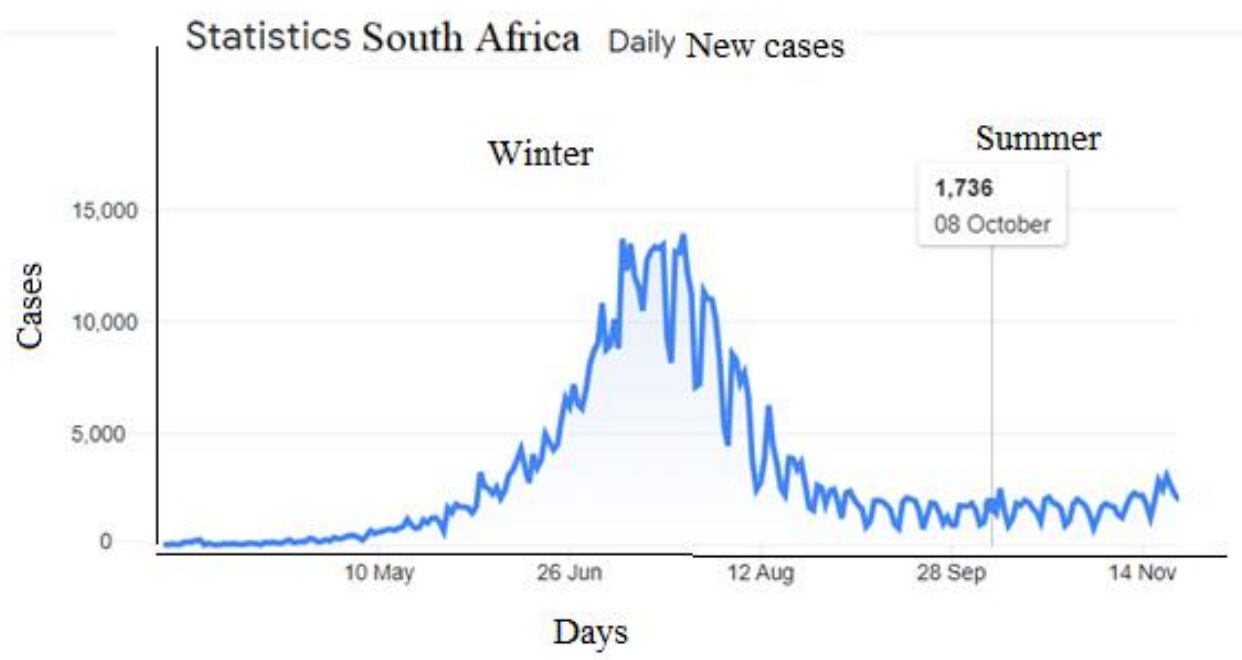

(e) 


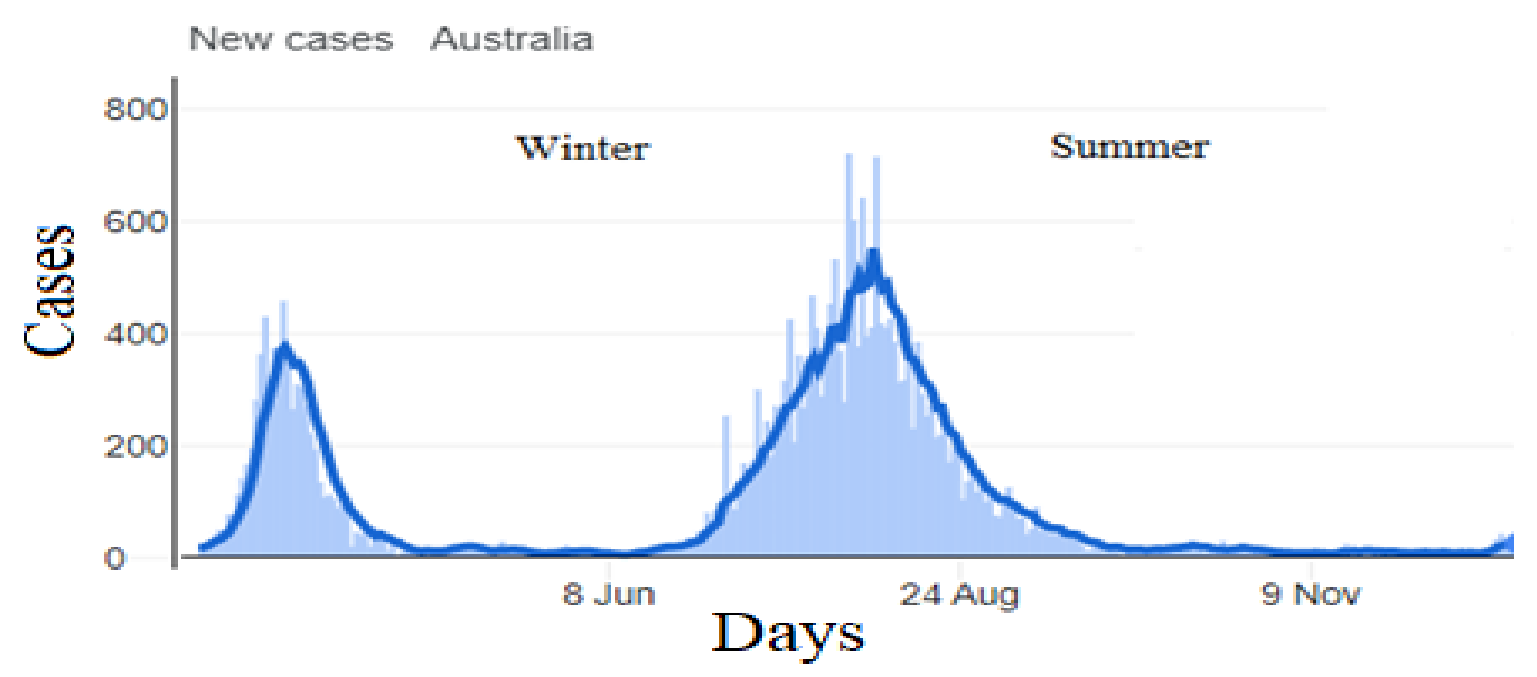

(f)

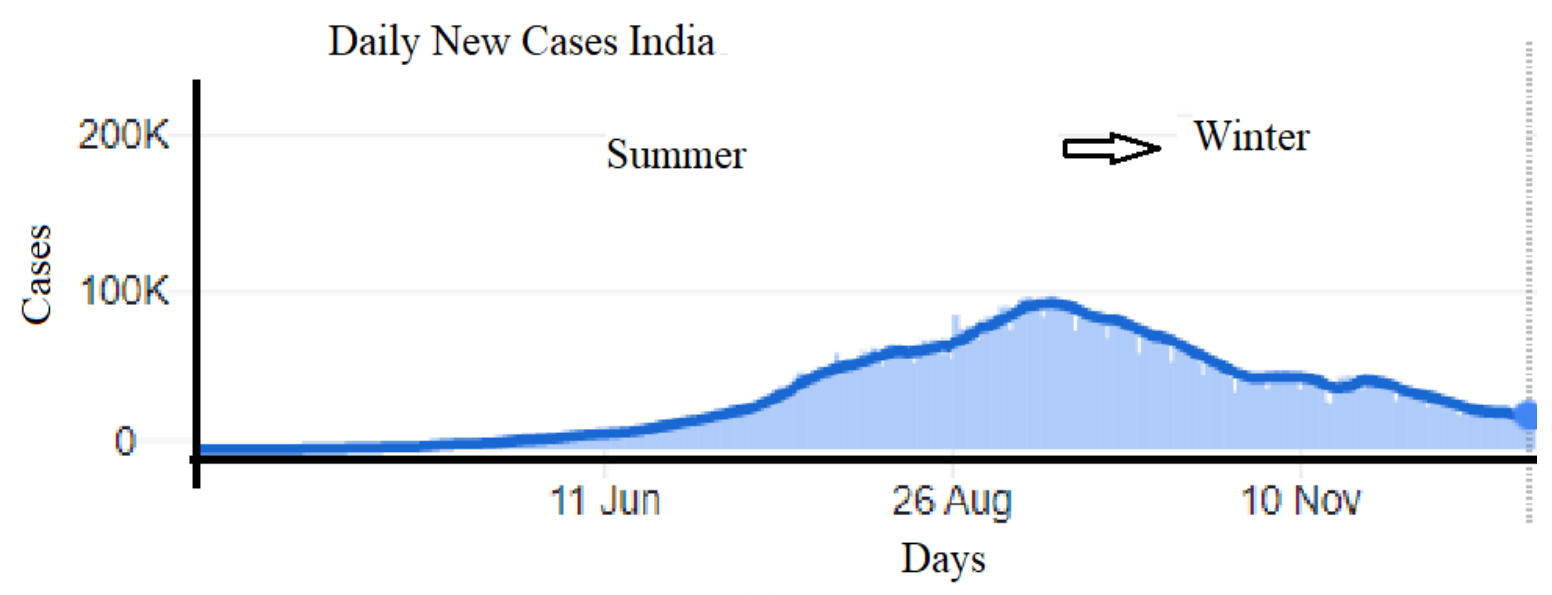

(g)

Figure 6 : COVID 19 active cases (from early 2020 to December 2020) at different countries. Note : a surge of COVID-19 cases was experienced in winter by most of the countries as displayed, India is an exception .

\section{3 : Meteorological role on Pandemic causalities}

Next, we examine the involvement of meteorological parameters in spreading ( or in inhibition ) or sustaining the epidemic/pandemic cases and causalities, especially in places like Russia where winter is very severe. One of the most significant factors here is perhaps the effect of snow fall on the growth of virus or otherwise. Therefore, we take up a brief analysis on the effect of snowfall on pandemic causalities of Russia during October 2020 to December 2020 , when a surge of COVID-19 death was 
reported. Further, the temperature role on causalities as cannot be ignored, the analysis also includes Temperature minimum (Tmin) value along with snowfall data. The correlation analysis between the pandemic death, Tmin and snowfall (when present) are thus worked out and presented in form of graphs separately for each month in Figure 7. The presence of an inverse relation between Tmin and causalities during October and November (Figures 7 a,b) 2020, is present. Though not strong (Figure 7a,b), an increase in mortality rate is seen as Tmin goes low (with correlation coefficient $\mathrm{Roc}=0.32, \mathrm{Rnov}=0.45$ ).But in December, unlike this inverse association, there prevailed a complex relation between the death and Tmin. The only extra parameter involved in December with that from October and November is the snow- fall from the beginning of the month (Figure 7c), the thickness of which increases as winter progresses. Therefore, contribution of snowfall to the causalities on December cannot be ruled out and infect the complex relation prevailed between Tmin, causalities and snowfall involved three basic features which are: (i) during early part of the month with thin layer of snow, the causalities show a decreasing trend with Tmin, a feature goes against to what is generally expected; (ii) with practically no snowfall for a brief period, the inverse relation between the pandemic death and Tmin appeared and finally (iii) with increase in snow thickness $(>10 \mathrm{~cm})$, the death rate slows down ( Figure $7 \mathrm{c}$ ).

We agree that such analysis needs involved studies by associating more cases with snow fall thickness and pandemic causalities. Also, that our observations related to the increase in the number of 'pandemic/epidemic' casualties during winter, might also have contributions from many other factors. One such environmental constrain obviously is the necessity of sharing common and closer environments by the inhabitants and more so in places with severe winter spells. 
International Journal of Electronics and Applied Research (IJEAR) vol. 7, issue 2, Dec 2020 Online (http://eses.net.in/online_journal.html)
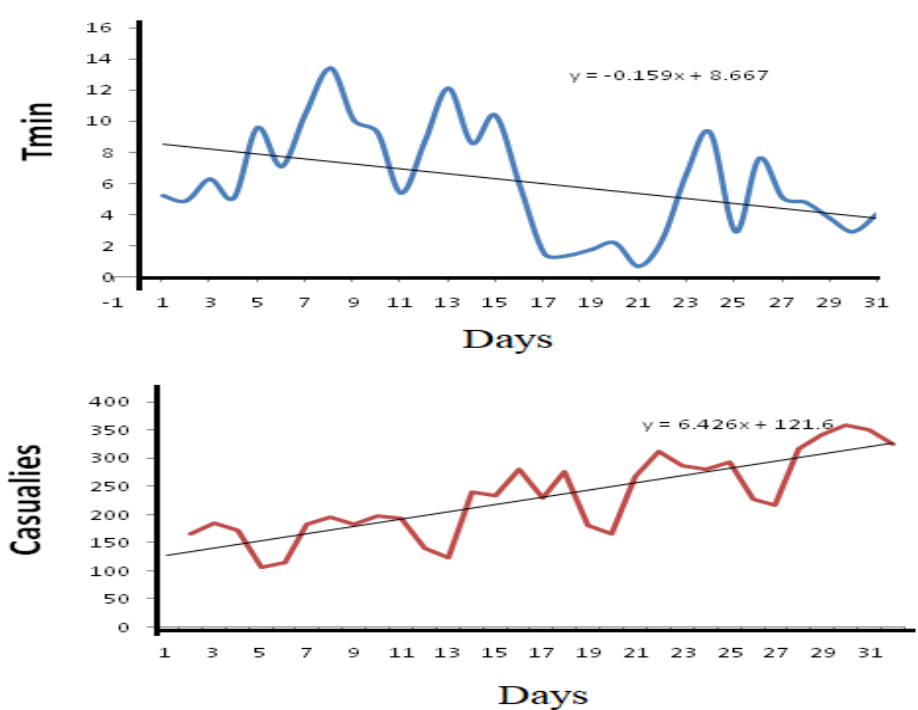

(a)
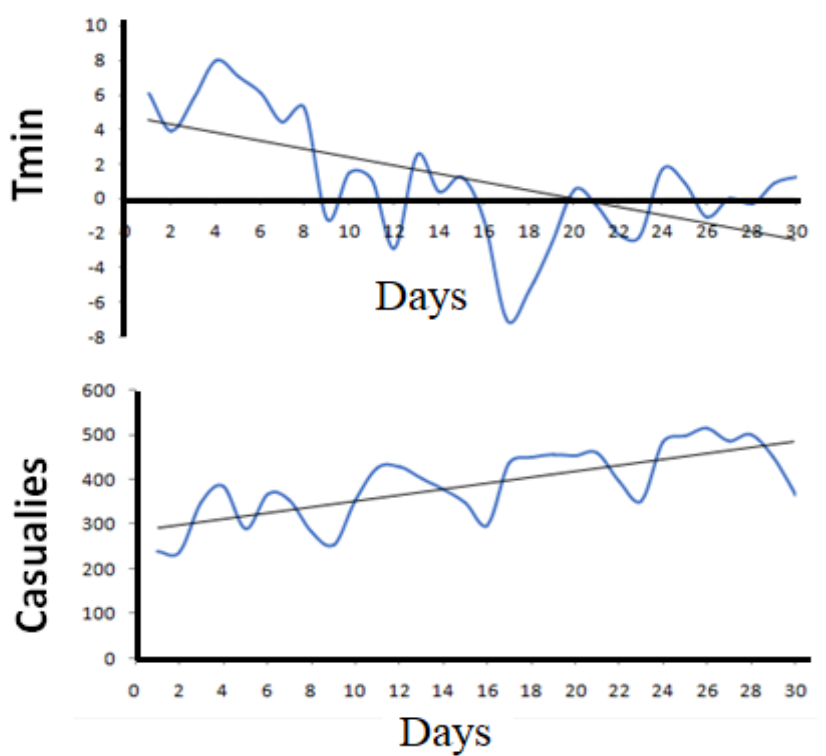

(b) 

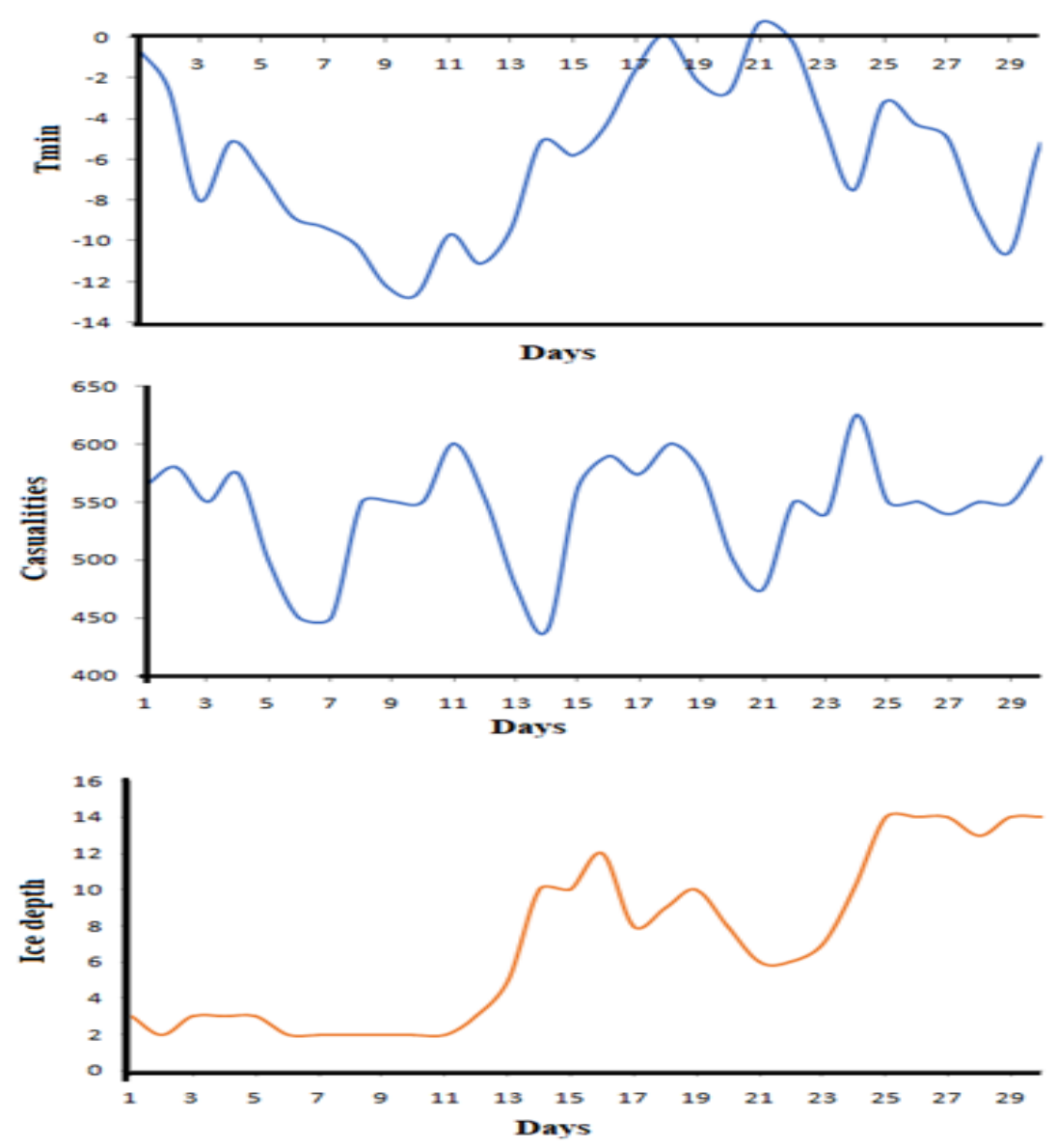

(c)

Figure $7: \mathrm{T}_{\min }\left({ }^{\circ} \mathrm{C}\right)$, pandemic causalities (numbers) and ICE depth $(\mathrm{cm})$ relation over Russia during October December 2020 :(a) October, no snowfall and inverse relation between $\mathrm{T}_{\min }$ and casualties ; (b) November snowfall only for $2-3$ days (not shown) inverse relation between $T_{\min }$ and casualties : (c) December, presence of complex relation between $\mathrm{T}_{\min }$, casualties and ICE depth.

\section{Discussions:}

The contribution of solar activity to the outbreak or spread of epidemic/pandemic is not a new topic . But even to this day the study seems to be controversial with explanations and results vary from one to the other observer. Ertel (1994) while analyzing pandemic cases from 1700 to 1985 showed that the events coincide with solar minimum while Tapping et al., [2001] studying influenza pandemics and sunlight activity, concluded that pandemics seem to coincide with the highest solar activity and also that the coincidence-chance in the observation is even less than 2\%. Yeung [2006] reported that seven 
pandemics between 1700 and 2000 are associated with incrementing solar activity status. This result was supported by Vaquero and Gallego [2007] . Observations and comments on seasonal effect on pandemic outbreak [Christiane et al., 2009; Kelly 2010, Kelly et al., 2010 ] are also available along with reviews on many aspects of pandemics [Hope-Simpson and Golubev 1987 ; Hope-Simpson 1992; Flahault and Zylberma; Zepeda-Lopez et al., Pedroni et al., 2010 ].

Therefore, our observation presented in the paper showing more pandemic/epidemic outbreaks around solar minimum goes along with some earlier reports. However as the solar cycle strength is highly variable from one to the other ( Figures 2 and 3), the direct relation with SN as presented here provides a better view to such analysis. We note that the status of SN when goes as low as 0-50, it coincides with the peak activity of pandemic/epidemic outbreak. It is also observed that except for a few pandemics like Asian flu (1957) no devastating pandemic outbreaks were reported within the highest solar peak with SN varying between 250-300 . But relatively more epidemic/pandemic events were reported within 150 $\geq \mathrm{SN}>100$ range , though SN with 150 may be the peak solar status for some cycles and could also be $20 \%$ below the peak for some other cycles. It is expected that during energetic solar cycle, the survival chances of pandemic viruses will be low. Because one of the components of solar radiation the UV that comprises though $10 \%$ of total radiation budget from sun (with 50\% infrared light, $40 \%$ visible light), is very effective in destroying killer viruses. Even from mid- twentieth century there were reports available for the use of UV irradiation for reducing influenza epidemics [McLean 1956] also sensitivity of SARS corona virus to heating and UV irradiation [ Duan et al., 2003] .We may refer here to the recent experiment of Christiane et al., [2020] who have demonstrated that SARS-CoV-2, causing acute respiratory problem that was identified in China in December (CoVID -19, could be inactivated rapidly by UVC irradiation even at high viral titers.

During solar minimum, the intensity of solar radiation reduces and may come down from its constant values of $1390 \mathrm{~W} / \mathrm{m} 2$ to $1360.5 \mathrm{w} / \mathrm{m} 2$ ( as in 2019 GOVID-19 case), thereby reducing its intensity by more than $2 \%$, thus UV radiation also loses effectiveness in controlling the virus compared to the solar peak status. Along with this line of explanation, there are reports stating that at low solar cycle, the intensity of cosmic rays which may increase enormously (like in 2019 with record low cycle status ), the enhanced strength of cosmic ray becomes the potential in mutating human skin cells make it vulnerable for viral infections [Chapanov \& Gorshkov 2019] , this aspect we have however not studied or analyzed in this article. 
Why not at the peak solar cycle but just below?

It is rather difficult to provide the physical or dynamical explanations involved in appearance of more number of pandemic events at $20 \%$ to $40 \%$ below the peak of the solar activity status. One of the explanations might be sought in the active role of solar radiation to the process of ionization of atmospheric constituents of the ionosphere. There exist a very good relation between solar activity \& Ionization density and approaches are adopted therefore to remove their contributions when special study demands [lastovisca et al., 2008 and many others]. There are situations especially at the peak solar condition when with the increase in energy of UV radiations more is the formation of ionization density. Therefore, a part of energy may be lost in ionization processes and at the peak cycle the UV though could retain enough of its energy but below its $20 \%$ to $40 \%$ ( or SN within 100-200), the effective energy (specially UV) (in the process of ionization) may not be strong to inhibiting the growth of the virus.

Perhaps, the Asian flu of 1960 solar cycle ( $\mathrm{SN}=>300$ ) that occurred at the most intense solar peaks (Figures 2 and 3 ), could be due to the loss of radiated energy in the process of ionisation making the effective solar intensity lower than available for killer viruses. Because reported case presentation shows [Fang et al., 2012] that almost 40\% to $50 \%$ enhancement in peak density of F2 layer of the ionosphere (foF2) occurred during strong solar cycle of 1960 and also in 1980, in comparison to that of very low solar status periods of 1970 and 2000 with weak solar flux. Such increase in density being associated with ultraviolet and other radiation from the sun (laymenn Alpha, Laymen Beta), there is no doubt that a part of energy may be associated with such exchange processes and energy losses are higher than usual making 'solar peak-period energy' less effective maybe less by $20 \%$ to $30 \%$, depending on the SN (like that of 1960 period). Thus, the resultant solar condition eventually becomes favourable for the growth of pandemic/epidemics, though apparently it is at the peak of the cycle. Through statistical model, the effect of EUV on Total Electron Content (TEC) was also reported by Lean et al.,[2010] showing that there may be a change of around 40 TEC $U(1 \mathrm{TECU}=1016 \mathrm{el} \mathrm{m-2})$ from solar maximum of 2002 to solar minimum 2008. Therefore, contribution of EUV to the ionization processes is significant and may be one of the critical factors in availability of the total energy for a virus to sustain its growth during a solar maximum, in spite of high $\mathrm{SN}$ values of that period.

In winter, the weak IR energy may one of the reasons resulting to the enhancement of pandemic cases especially at low solar cycle period when UV radiation is already low in strengths. Along with this background, the meteorological variabilities are likely to contribution to pandemic causalities as we see 
in our brief study conducted over high-mid latitude station Moscow of Russia where winter is severe. We have observed that snowfall has a good contribution to the pandemic causalities both by its shielding /absorbing and reflecting properties. The albedo and absorption features working along with the background temperature do provide control to the pandemic death during December 2020. Because, there will be increases in the amount of absorbed radiation with decrease of albdeo. If albedo of a surface drops from 0.90 to 0.85 , the amount of absorbed radiation then increases by $50 \%$. In other words, the amount of absorbed radiation increases rapidly when the albedo of a high-albedo surface is lowered. Thus, with depth $>10 \mathrm{~cm}$, the snow acts as a shielding and allowing the more radiation to be absorbed unlike thin bright snow layer reflecting back the solar energy. Thus the shielding is likely to bring down the death rate. However one month snow fall data is not sufficient to draw a reliable conclusion.

The associations of pandemic causalities or infected cases with season, are finally governed by complex dynamics not only by the atmospheric/meteorological parameters but also involved human behavior and activity. Like in India, more cases that were detected during summer are from relatively warm zones when public cooling system might have been in operation, which perhaps seeding the spreading process. A few countries with the initiative on enforcement of protocol and other socio economic conditions might have contained the spread with immediate effect by not allowing the virus to grow .Further, every country/region has its different mode of seasonal transmission of diseases resulting to high causalities. Like in USA the high mortality during the winter period is suggested [Thomas et al., 2004] to be probably influenza, along with temperature/weather and infectious agents. So such status may further modulate the pandemic causalities during that period. Also suggested by Kelly [2010], that pandemic has a strong modulation by seasonal intensity of influenza.

Therefore, we conclude that the role of solar activity in the growth of virus is present and more in the specific sunspot zone i.e., near to the lowest solar activity status when UV the high energetic ray strength reduces (specially in 2019 period). In cold countries snow fall depth may contain or accelerate the causality rate, based on the type of snow whether reflecting or absorbing type (more studies to be conducted if possible). The winter season though has a favorable environment (low solar ambiances) and summer has low probability of virus to grow but its spread is also controlled by many other socio economic parameters as mentioned. Finally, we must say that this study does not cover the issues related to the origin of a virus and its biological aspects either born in natural or artificial environment also on the multi mutation processes of a virus. The entire analysis dedicates to identifying solar and relevant 
environmental status which is convenient and congenital for the virus to grow ( once born), and survive . Thus, as our aim requires we have identified the state of solar-environmental backgrounds comfortable for a virus to outbreak a pandemic/epidemic but for the spread and sustenance of the events these are challenges to the global community.

\section{Acknowledgements:}

The authors Devi, Barbara and Depueva acknowledge with thanks the DST, India for supporting the work thorough RFBI project. The Mitsubishi foundations of Japan were duly acknowledged by Devi and Oyama for the offer of partial financial assistances to this joint programme.

\section{Reference}

Chapanov, Ya.\& V. Gorshkov (2019) Solar Activity and Cosmic Ray Influence on the Climate Geomagnetism and Aeronomy 59, 942-949.

Christiane Silke Heilingloh, Ulrich Wilhelm Aufderhorst, Leonie Schipper, Ulf Dittmer, Oliver Witzke 1, Dongliang Yang, Xin Zheng, Kathrin Sutter, Mirko Trilling, Mira Alt, Eike Steinmann, Adalbert Krawczyk (2020) Susceptibility of SARS-CoV-2 to UV irradiation, Am J Infect Control. Oct; 48(10): 1273-1275.Published online 2020 Aug 4. doi: 10.1016/j.ajic.2020.07.031

Duan S M, X S Zhao, R.F. Wen, J J Huang, G H Pi, S X Zhang, J Han ,S.L Bi, L Ruan , X P Dongand SARC Research Team ( 2003), Stability of SARS coronavirus inhuman specimens and environment and its sensitivity to heating and UV irradiation . Biomed Environ Sci. 16, 246-255

Ertel, S. (1994) Influenza pandemics and sunspots-easing the Controversy. Nature wissenschaften 81(7): 308-311. Google Scholar

Fang Han Xian, Weng LiBin, Yang Sheng Gao \& Wang SiCheng, (2002), Long-term trends in foF2 over Moscow ionosonde station: Its estimate and origins , Chineese Science Bulletin 1448-ECIAL ISSUE April 2012 Vol.57 No.12: 1443 Basic Plasma Processes in sola Terrestrial activities, doi 10.1007/s 11434-012--5046-X

Flahaul Antoinet and Patrick Zylberman ( 2010 ), ,Influenza pandemics: past, present and future challenges , Public Health Reviews, Vol. 32, No 1, 319-340

Hope-Simpson R. E (1978), Sunspots and flu: a correlation, Nature , 275, 86.

Hope-Simpson RE and Golubev DB (1987), New concept of the epidemic process of influenza A Virus Epidemiol Infect, 99, 5-54 
Hope-Simpson RE ,(1992), New concept of the epidemic process of influenza A Virus: ,The Transmission of Epidemic Influenza, Newwork Plenum press .

Kelly M Heath A ed J Aust (2010), A pandemic response to a disease of predominantly seasonal intensity , 192 (2): 81-83. || doi:10.5694/j.1326-5377.2010.tb03423.x Published online: 18 January 2010

Kelly PM, Lokuge K, Cameron AS. (2010) A pandemic response to a disease of predominantly seasonal intensity. Comment. (2010), Med J Aust.; 93(10):623-4

Lastovi $`{ }^{-}{ }^{`}$ J. , X. Yue and W. Wan, (2008), Long-term trends in foF2: their estimating and origin, Ann. Geophys., 26, 593-598, 2008 www.ann-geophys.net/26/593/2008/ @ European Geosciences Union 2008

Lean J. L., R. R. Meier J. M. Picone F. Sassi J. T. Emmert P. G. Richards (2016), Ionospheric total electron content: Spatial patterns of variability, JGR: Space Physics ;https.doi.org/10.1002/2016 JA023210

McLean, R. L. (1956) Comments on reducing influenza epidemics among hospitalized veterans by UV irradiation of droplets in the air. Amer. Rev. Respiratory Dis. 83(Suppl), 36- 38.

Munneke P K ,Snow, (2009) ice and solar radiation ,printing Ipskamp Drukkers BV, Enschede, ISBN 978-90-393-514-2

Pedroni E, Garcia M, Espinola V, Guerrero A, Gonzalez C, Olea A, et al.(2010), Outbreak of 2009 pandemic influenza A(H1N1), Los Lagos, Chile, April- June 2009. Euro Surveill. 15(1)

Qu J (2016) Is sunspot activity a factor in influemza pandemics ? Rev Med Virol 26 \%s 309-313.

Tapping, KF, Mathias, RG, Surkan, DL (2001),Influenza pandemics and solar activity, Canadian Journal of Infectious Diseases, 12 ,61-62

Thomas A Reichert, Lone Simonsen, Ashutosh Sharma, Scott A Pardo, David S Fedson, Mark A Miller (2004), Influenza and the winter increase in mortality in the United States, 1959-1999, Am J Epidemiol, Sep 1;160(5):492-502. doi: 10.1093/aje/kwh227.

Towers S., (2017), Sunspot activity and influenza pandemics: a statistical assessment of the purported association, Published on line by Cambridge University Press, 29 August 2017.

Vaquero JM, Gallego MC (2007) Sunspot numbers can detect pandemic influenza A: the use of different sunspot numbers , Med Hypotheses, 68, 1189-1190 . http/doi.org /10.1016/J. mehy.2006.10.021

Yeung, J W K. (2006), A hypothesis: sunspot cycles may detect pandemic influenza a in 1700-2000 ad. Medical Hypotheses , 67(5): 1016-1022. 
Zepeda- Lopez HM, Perea- Araujo L, Miliar- Garcia A, Dominguez- Lopez A, Xoconostle- Cazarez B, Lara- Padilla E, et al. (2010), Inside the outbreak of the 2009 influenza A (HINI) virus in Mexico. PLoS PLoS One. ;5(10):e13256.

Zhu N, Zhang D, Wang W. (2020), A novel corona virus from patients with pneumonia in China, 2019. $N$ Engl J Med. 2020;382:727-733. [PMC free article] [PubMed]

Other Sources :

Spanish pandemic flu by 2011 [Online] 2011 Available from

URL: http://www.ncbi.nlm.nih.gov/pubmed?term=Spanish\%20pandemic\%20flu\%20by\%202011/

Commission of the European Communities. Pandemic (H1N1)2009 Communication from the Commission to the European Parliament, the Council, the European Economic and Social Committee and the Committee of the Regions. Luxembourg: Office for Official Publications of the European Communities; 2009

List of epidemics - Wikipedia Almost all the historical backgrounds of pandemic/epidemic from BC to the recent events are framed from this source. 
Table I

Events from mid $18^{\text {th }}$ century, the considered cases only

\begin{tabular}{|c|c|c|c|c|}
\hline Events & $\begin{array}{l}\text { utbreak } \\
\text { year }\end{array}$ & Country of Origin & $\begin{array}{l}\text { Type of epidemic } \\
\text { / pandemic }\end{array}$ & Causalities \\
\hline $\begin{array}{l}\sqrt{\text { Russian }} \\
\text { plague of } \\
1770-1772\end{array}$ & $\begin{array}{l}1770- \\
1772\end{array}$ & Russia & Bubonic plague & 50,000 \\
\hline $\begin{array}{l}\sqrt{1772-1773} \\
\text { Persian } \\
\text { Plague }\end{array}$ & $\begin{array}{l}1772- \\
1773\end{array}$ & Persia & Bubonic plague & 2 million+ \\
\hline $\begin{array}{l}\sqrt{ } 1789-1790 \\
\text { New South } \\
\text { Wales } \\
\text { smallpox } \\
\text { epidemic }\end{array}$ & $\begin{array}{l}1789- \\
1790\end{array}$ & New South Wales, Australia & Smallpox & $\begin{array}{l}\text { Unknown } \\
\text { (50-70\% of } \\
\text { native } \\
\text { population) }\end{array}$ \\
\hline $\begin{array}{l}\sqrt{ } 1800-1803 \\
\text { Spain yellow } \\
\text { fever } \\
\text { epidemic }\end{array}$ & $\begin{array}{l}1800- \\
1803\end{array}$ & Spain & Yellow fever & $60,000+$ \\
\hline $\begin{array}{l}\sqrt{ } 1802-1803 \\
\text { Saint- } \\
\text { Domingue } \\
\text { yellow fever } \\
\text { epidemic }\end{array}$ & $\begin{array}{l}1802- \\
1803\end{array}$ & Saint-Domingue & Yellow fever & \begin{tabular}{|l|}
$29,000-$ \\
55,000
\end{tabular} \\
\hline $\begin{array}{l}\sqrt{ } 1812 \text { Russia } \\
\text { Typhus } \\
\text { epidemic }\end{array}$ & 1812 & Russia & Typhus & 300,000 \\
\hline $\begin{array}{l}\sqrt{1812-19} \\
\text { Ottoman } \\
\text { plague } \\
\text { epidemic }\end{array}$ & $\begin{array}{l}1812- \\
1819\end{array}$ & Ottoman Empire & Bubonic plague & $300,000+$ \\
\hline
\end{tabular}


International Journal of Electronics and Applied Research (IJEAR) vol. 7, issue 2, Dec 2020 Online (http://eses.net.in/online_journal.html)

\begin{tabular}{|c|c|c|c|c|}
\hline $\begin{array}{l}\sqrt{\text { Caragea's }} \\
\text { plague }\end{array}$ & 1813 & Romania & Bubonic plague & 60,000 \\
\hline $\begin{array}{l}\sqrt{ } 1817-1819 \\
\text { Ireland typhus } \\
\text { epidemic }\end{array}$ & $\begin{array}{l}1817- \\
1819\end{array}$ & Ireland & Typhus & 65,000 \\
\hline $\begin{array}{l}\sqrt{\text { First cholera }} \\
\text { pandemic }\end{array}$ & $\begin{array}{l}1817- \\
1824\end{array}$ & Asia, Europe & Cholera & $100,000+$ \\
\hline $\begin{array}{l}\sqrt{\text { Second }} \\
\text { cholera } \\
\text { pandemic }\end{array}$ & $\begin{array}{l}1826- \\
1837\end{array}$ & Asia, Europe, North America & Cholera & $100,000+$ \\
\hline $\begin{array}{l}\sqrt{ } 1829-1833 \\
\text { Pacific } \\
\text { Northwest } \\
\text { malaria } \\
\text { epidemic }\end{array}$ & $\begin{array}{l}1829- \\
1833\end{array}$ & Pacific Northwest, United States & $\begin{array}{l}\text { Malaria, possibly other } \\
\text { diseases too }\end{array}$ & 150,000 \\
\hline $\begin{array}{l}\sqrt{\text { Third }} \\
\text { cholera } \\
\text { pandemic }\end{array}$ & $\begin{array}{l}1846- \\
1860\end{array}$ & Russia & Cholera & 1 million+ \\
\hline $\begin{array}{l}\sqrt{\text { Third plague }} \\
\text { pandemic }\end{array}$ & $\begin{array}{l}1855- \\
1960\end{array}$ & Worldwide & Bubonic plague & $\begin{array}{l}12 \text { million+ } \\
\text { (India and } \\
\text { China) }\end{array}$ \\
\hline $\begin{array}{l}\sqrt{1861-1865} \\
\text { United States } \\
\text { typhoid fever } \\
\text { epidemic }\end{array}$ & $\begin{array}{l}1861- \\
1865\end{array}$ & United States & Typhoid fever & 80,000 \\
\hline $\begin{array}{l}\sqrt{\text { Fourth }} \\
\text { cholera } \\
\text { pandemic }\end{array}$ & $\begin{array}{l}1863- \\
1875\end{array}$ & Middle East & Cholera & 600,000 \\
\hline
\end{tabular}




\begin{tabular}{|c|c|c|c|c|}
\hline $\begin{array}{l}\sqrt{ } 1870-1875 \\
\text { Europe } \\
\text { smallpox } \\
\text { epidemic }\end{array}$ & $\begin{array}{l}1870- \\
1875\end{array}$ & Europe & Smallpox & 500,000 \\
\hline $\begin{array}{l}\sqrt{\text { Fifth cholera }} \\
\text { pandemic }\end{array}$ & $\begin{array}{l}1881- \\
1896\end{array}$ & Asia, Africa, Europe, South America & Cholera & 298,600 \\
\hline $\begin{array}{l}\sqrt{1889-1890} \\
\text { flu pandemic }\end{array}$ & $\begin{array}{l}1889- \\
1890\end{array}$ & Worldwide & $\begin{array}{l}\text { Influenza or HCoV- } \\
\text { OC43 }\end{array}$ & 1 million \\
\hline $\begin{array}{l}\sqrt{ } 1896-1906 \\
\text { Congo Basin } \\
\text { African } \\
\text { trypanosomia } \\
\text { sis epidemic }\end{array}$ & $\begin{array}{l}1896- \\
1906\end{array}$ & Congo Basin & $\begin{array}{l}\text { African } \\
\text { trypanosomiasis }\end{array}$ & 500,000 \\
\hline $\begin{array}{l}\sqrt{\text { Sixth }} \\
\text { cholera } \\
\text { pandemic }\end{array}$ & $\begin{array}{l}1899- \\
1923\end{array}$ & Europe, Asia, Africa & Cholera & $800,000+$ \\
\hline $\begin{array}{l}\sqrt{1900-1920} \\
\text { Uganda } \\
\text { African } \\
\text { trypanosomia } \\
\text { sis epidemic }\end{array}$ & $\begin{array}{l}1900- \\
1920\end{array}$ & Uganda & $\begin{array}{l}\text { African } \\
\text { trypanosomiasis }\end{array}$ & $\begin{array}{l}200,000- \\
300,000\end{array}$ \\
\hline $\begin{array}{l}\sqrt{\text { Manchurian }} \\
\text { plague }\end{array}$ & $\begin{array}{l}1910- \\
1911\end{array}$ & China & Pneumonic plague & 60,000 \\
\hline $\begin{array}{l}\sqrt{1915} \\
\text { Encephalitis } \\
\text { lethargica } \\
\text { pandemic }\end{array}$ & $\begin{array}{l}1915- \\
1926\end{array}$ & Worldwide & Encephalitis lethargica & 1.5 million \\
\hline $\begin{array}{l}\sqrt{1918} \\
\text { influenza } \\
\text { pandemic } \\
\text { ('Spanish flu') }\end{array}$ & $\begin{array}{l}1918- \\
1920\end{array}$ & Worldwide & $\begin{array}{l}\text { Influenza A virus } \\
\text { subtype H1N1 }\end{array}$ & $\begin{array}{l}50 \text { million+ } \\
(17-100 \\
\text { million })-(3- \\
5 \% \text { world's }\end{array}$ \\
\hline
\end{tabular}




\begin{tabular}{|c|c|c|c|c|}
\hline & & & H1N1 virus & population) \\
\hline $\begin{array}{l}\sqrt{1918-1922} \\
\text { Russia typhus } \\
\text { epidemic }\end{array}$ & $\begin{array}{l}1918- \\
1922\end{array}$ & Russia & Typhus & 2.5 million \\
\hline $\begin{array}{l}\sqrt{1957-1958} \\
\text { influenza } \\
\text { pandemic } \\
\text { ('Asian flu') }\end{array}$ & $\begin{array}{l}1957- \\
1958\end{array}$ & Worldwide & $\begin{array}{l}\text { Influenza A virus } \\
\text { subtype H2N2 }\end{array}$ & 1-4 million \\
\hline $\begin{array}{l}\sqrt{\text { Hong Kong }} \\
\text { flu }\end{array}$ & $\begin{array}{l}1968- \\
1970\end{array}$ & Worldwide (mainly in Hong Kong) & $\begin{array}{l}\text { Influenza A virus } \\
\text { subtype } \mathrm{H} 3 \mathrm{~N} 2\end{array}$ & 1-4 million \\
\hline $\begin{array}{l}\sqrt{\text { HIV/AIDS }} \\
\text { pandemic }\end{array}$ & $\begin{array}{l}\text { 1981- } \\
\text { prese } \\
\text { nt } \\
\text { (data } \\
\text { as of } \\
2018 \text { ) }\end{array}$ & Worldwide & $\begin{array}{l}\text { HIV/AIDS } \\
\text { Human immunodeficiency } \\
\text { virus }\end{array}$ & $\begin{array}{l}32 \text { million+ } \\
(23.6-43.8 \\
\text { million) }\end{array}$ \\
\hline $\begin{array}{l}\sqrt{2009} \text { swine } \\
\text { flu pandemic }\end{array}$ & $\begin{array}{l}2009- \\
2010\end{array}$ & Worldwide & $\begin{array}{l}\text { Influenza A virus } \\
\text { subtype H1N1 }\end{array}$ & $\begin{array}{l}\text { Lab confirmed } \\
\text { deaths: } \\
18,449 \\
\text { (reported to } \\
\text { the WHO) } \\
\\
\text { Estimated } \\
\text { death toll: } \\
284,000 \\
\text { (possible } \\
\text { range } \\
151,700- \\
575,400)\end{array}$ \\
\hline $\begin{array}{l}\sqrt[3]{2017-18} \\
\text { I Inited States }\end{array}$ & $\begin{array}{l}2017- \\
2018\end{array}$ & United States & Seasonal influenza & $\begin{array}{l}61,000 \\
(46,000- \\
\end{array}$ \\
\hline
\end{tabular}


International Journal of Electronics and Applied Research (IJEAR) vol. 7, issue 2, Dec 2020 Online (http://eses.net.in/online_journal.html) ISSN 2395-0064

\begin{tabular}{|c|c|c|c|c|}
\hline flu season & & & & $95,000)^{[263]}$ \\
\hline $\begin{array}{l}\sqrt{\text { COVID-19 }} \\
\text { pandemic }\end{array}$ & $\begin{array}{l}\text { 2019- } \\
\text { prese } \\
\text { nt }\end{array}$ & Worldwide & 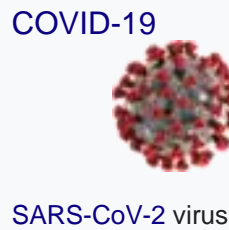 & $\begin{array}{l}1.2 \text { million+ } \\
\text { (as of } \\
\text { November } \\
2020 \text { ) }\end{array}$ \\
\hline
\end{tabular}

